\title{
Nutrition and carcinoma of the large intestine
}

\section{By J. H. Weisburger, Naylor Dana Institute, Dana Road, Valhalla, New York I0595, USA}

Based on various lines of evidence and multi-disciplinary approaches, it has been suggested that nutrition and specific nutritional components, as well as dietary habits, in various parts of the world may play an important role in the causation and development of a number of major types of cancer. Nutrition may relate directly to the occurrence of $30-40 \%$ of cancers in men and $50-60 \%$ of cancers in women in the USA and other Western countries (Hiatt et al. 1977; Doll \& Peto, I98I; Magnus, 1982; Wynder et al. 1983). We have dissected the overall carcinogenic process into a number of sequential steps, all of which are necessary for a clinically invasive cancer to occur (Fig. I) (Weisburger \& Horn, I98I; Weisburger \& Williams, 1981). This sequence has been demonstrated in numerous studies in animal models, and there is no reason to assume that this sequence would not also hold for the initiation, development, and progression of human cancers. In this scheme, the early events are the result of specific molecular changes caused by genotoxic carcinogens in cellular systems for cancers of the colon, breast, prostate, and perhaps even pancreas. We have noted that mutagens and also carcinogens are seen at the surface of fried or broiled foods such as meat or fish (Barnes et al. 1983; Sugimura et al. 1983). This concept, however, needs further validation through research currently being performed in a number of laboratories in Japan, Europe, and the USA. Gastric cancer, on the other hand, appears to be associated with totally distinct factors, namely, pickled and salted fish or beans and also residence in areas with geochemical or agricultural sources of nitrate intake, not balanced by the presence of vitamin $\mathrm{C}$, vitamin $\mathrm{E}$, or certain phenolic antioxidants and nitrite traps such as pyrogallol or tannins (Correa et al. I982; Weisburger \& Horn, 1982; Joossens \& Geboers, 1983). The possible genotoxic carcinogen may be a nitrosamide or aryldiazonium salt. The formation of such compounds is inhibited by vitamin $\mathrm{C}$, vitamin $\mathrm{E}$ and certain antioxidants (Mirvish, 1983). This fact can be used to decrease the risk of gastric cancer deliberately.

Epigenetic or promoting agents play a major role in the development of cancers of the colon, breast and prostate (Reddy et al. 1980; Hill, 1983; Wynder et al. 1983). Delineating the relevant epigenetic-promoting effects for cancer of the colon is important because whether or not overt invasive disease is seen depends a great deal on these epigenetic-promoting factors. These stem from the intake of appreciable amounts of dietary fat which are responsible for the endogenous production of specific non-genotoxic, epigenetic agents associated with increased risk. 


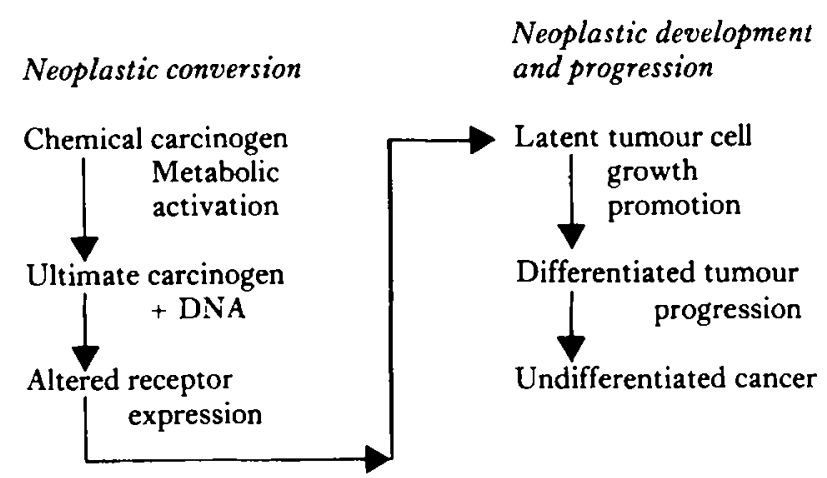

Fig. 1. Sequence of steps in the initiation, development and progression of human cancer.

For colon cancer, the major controlling dietary elements, relevant through studies in man and in animal models, are the amounts of dietary fat and fibre (Modan et al. 1975; Reddy et al. 1980; Wynder et al. 1983). One of the best arguments for this concept is the changing incidence of colon cancer in Japan in recent years as the Japanese nutritional intake became progressively westernized (Hirayama, I979). In addition, in many areas of the world, an association exists between colon cancer and coronary heart disease, where the amount of dietary fat and cholesterol have been shown to relate to the risk of heart disease. An interesting exception to this rule is Finland where the risk of heart disease is high and that of colon cancer low. There is some evidence that the lower risk of colon cancer in Finnish people, despite a high fat intake, is due to their consumption of foods high in fibre, especially cereal bran fibre (I.A.R.C. Microecology Group, 1977; Reddy et al. 1978, 1980; Wynder et al. 1983).

Research by a number of groups, particularly by Reddy et al. (1980) and by Nigro ( $198 \mathrm{I}$ ), has yielded insight into the mechanism whereby fat and cholesterol promote the risk of colon cancer and fibre inhibits colon carcinogenesis. The main effect of dietary fat appears to reside in a direct association between endogenous cholesterol biosynthesis which, when combined with exogenous cholesterol intake, leads to increased bile acid biosynthesis and excretion through the intestinal tract. Certain bile acids have been shown to be colon tumour promoters in both germ-free and conventional rats. Bile acids do not act as complete carcinogens, and their role is to act as promoters in the overall carcinogenic process (Reddy \& Watanabe, 1979; Reddy et al. 1980) Reddy \& Watanabe (1979) found that cholesterol metabolites, including the $\alpha$-epoxide or neutral sterols, not only did not by themselves, or by their metabolites produced by colonic bacteria, induce tumours in the colon of germ-free and conventional rats, but also had no promoting activity. Further studies are needed on the mechanisms whereby the bile acids enhance cell proliferation, and possibly also affect the functional differentiation of colonic cells during their upward migration in a crypt (Deschner, 1983; Lipkin, 1983).

The effect of some dietary fibres, such as cereal bran, is to increase intestinal and stool bulk, thereby reducing the concentration of promoters, effectively lowering 
the risk of development of colon cancer. The lower incidence of colon cancer in populations such as the Mormons and the Finns, who consume fried meat and other sources of genotoxic carcinogens and eat appreciable amounts of fat which lead to promotion, but who also eat sizable amounts of cereal grains, may thus be explained by stool bulk acting as a modulator of promotion by reducing bile acid concentration. Recently, Wargovich et al. $\left(198_{3}\right)$ have made the interesting finding, which has the potentially important application of reducing colon cancer risk, that dietary intake of calcium salts, a simple, easily carried out dietary change, decisively lowers the incidence of chemically-induced colon cancer in mice (Table 1).

More research is also needed on modulators and inhibitors, such as micronutrients, that would eventually find application in lowering human disease risk. The role of yellow-green vegetables, especially from the brassica family, in apparently lowering the risk of colon cancer, remains to be defined (Graham \& Mettlin, 1979; Wattenberg, 1983). It is not clear whether the active ingredients in such vegetables modify the metabolism of the genotoxic carcinogens associated with colon cancer, whether they play a role in bile acid production or further metabolism, or in the metabolism of other, as yet unknown, epigenetic-promoting agents.

Since these elements operate through epigenetic mechanisms, their action is, by definition, dose and time dependent. Thus, a reduction in effective dose, by whatever means, would be expected to lead to rather rapid lowering of risk, and hence of incidence. This applies even to patients with such diseases, where dietary intervention promises to be an effective adjuvant therapy (Wynder \& Cohen, 1982). When the postmenopausal use of oestrogen drugs such as Premarin was

Table I. Comparison of high and low risk dietary factors for cancer in specific organs

\begin{tabular}{|c|c|c|c|c|}
\hline \multirow[b]{2}{*}{ Organ } & \multicolumn{2}{|c|}{ High risk } & \multicolumn{2}{|r|}{ Lower risk } \\
\hline & Population & Dietary factors & Population & Dietary factors \\
\hline Stomach & $\begin{array}{l}\text { Japan, Chile, } \\
\text { Columbia }\end{array}$ & $\begin{array}{l}\text { Salted, pickled } \\
\text { food, nitrate }\end{array}$ & USA & $\begin{array}{l}\text { Fresh fruit salad, } \\
\text { vitamins } C \text { and } E\end{array}$ \\
\hline \multirow[t]{2}{*}{ Colon } & $\begin{array}{l}\text { USA, Western Europe, } \\
\text { New Zealand, } \\
\text { Australia, } \\
\text { Denmark }\end{array}$ & $\begin{array}{l}\text { High fat, low } \\
\text { fibre, } \\
\text { fried food }\end{array}$ & Japan & Low fat \\
\hline & & & $\begin{array}{l}\text { Mormons } \\
\text { Seventh Day } \\
\text { Adventists } \\
\text { Finland }\end{array}$ & $\begin{array}{l}\text { Higher fibre } \\
\text { Low or no fried food, } \\
\text { higher fibre } \\
\text { Higher fibre, lower fried } \\
\text { food }\end{array}$ \\
\hline Breast & $\begin{array}{l}\text { USA, Western Europe, } \\
\text { New Zealand, } \\
\text { Australia }\end{array}$ & $\begin{array}{l}\text { High fat, low } \\
\text { fibre, fried food }\end{array}$ & Japan & Low fat \\
\hline Prostate & $\begin{array}{l}\text { USA, Scandinavia, } \\
\text { Western Europe }\end{array}$ & High fat & Japan & Low fat \\
\hline
\end{tabular}


Table 2. Nutritional factors involved in certain human cancers (Weisburger $\mathbb{F}^{\circ}$ Horn, 1982)

\begin{tabular}{|c|c|c|c|}
\hline $\begin{array}{l}\text { Source of genotoxic } \\
\text { carcinogen }\end{array}$ & $\begin{array}{l}\text { Enhancing } \\
\text { factors }\end{array}$ & $\begin{array}{l}\text { Inhibiting } \\
\text { factors }\end{array}$ & $\begin{array}{l}\text { Organs } \\
\text { affected }\end{array}$ \\
\hline $\begin{array}{l}\text { Nitrite }+ \text { specific foods } \\
\text { (Fish, beans, not meats) }\end{array}$ & Salt & $\begin{array}{l}\text { Vitamin C } \\
\text { Vitamin E } \\
\text { Propyl gallate } \\
\text { Tannins }\end{array}$ & $\begin{array}{l}\text { Stomach } \\
\text { Oral cavity } \\
\text { Oesophagu }\end{array}$ \\
\hline Fried foods & Fat & $\begin{array}{l}\text { Fibre, vitamins, } \\
\text { minerals (Se } \\
\text { salts, Zn ion, } \\
\text { Ca ion, others?), } \\
\text { microwave cooking, } \\
\text { antioxidants or } \\
\text { soya-bean protein in } \\
\text { cooking }\end{array}$ & $\begin{array}{l}\text { Colon } \\
\text { Breast } \\
\text { Prostate } \\
\text { Pancreas }\end{array}$ \\
\hline
\end{tabular}

discontinued, there was a rapid decline in endometrial cancer (Austin \& Roe, 1982), witness that epigenetic phenomena are reversible.

If current research does document further that the mode of cooking, especially frying and broiling, yields carcinogens for colon cancer, means are available to lower the formation of such agents (Pariza et al. 1983; Weisburger et al. 1983). Furthermore, and importantly, if colon cancer risk is indeed associated with the level of dietary fat and inversely with the amount of cereal fibre, with the concentration of bile acids as the crucial element in the promoting process, this evidence can be the basis for suggesting relatively minor alterations in dietary habits involving mainly a lower fat intake and a higher fibre consumption as tools to lower disease risk (Table 2). Along these lines, research on optimal levels of vitamins, minerals and other micronutrients, as well as antioxidants and certain

Risk factors: Diets high in fat, cholesterol, fried foods, and low in fibre and vegetables

\section{Established mechanisms}

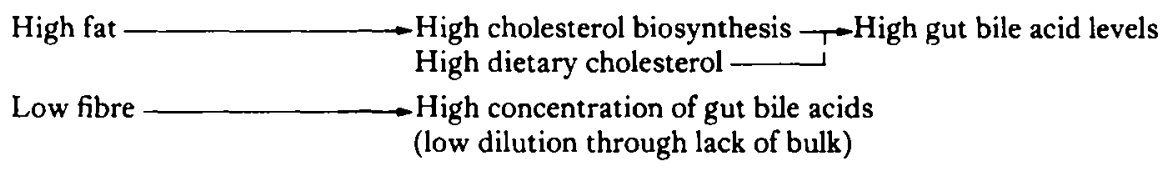

High bile acid concentration $\longrightarrow$ Promoting effect in colon carcinogenesis

Mechanisms under study

Fried food -Mutagens Colon carcinogens? Role of micronutrients (vitamins and minerals) and different types of fibre in production and metabolism of carcinogens, bile acids, promoters?

Mechanisms of promotion?

Fig. 2. Current concepts on colon cancer causation and development 
indoles, in the current diet would provide a broad basis for chemoprevention. Over the last several years, research has provided new perspectives on the causes and modifiers of the main premature killing diseases. Fig. 2 shows some of the underlying mechanisms involved in the development of colon cancer. An understanding of these mechanisms should provide a basis for the prevention of colon cancer and the long term goal of disease prevention.

\section{REFERENCES}

Austin, D. F. \& Roe, K. M. (1982). American fournal of Public Health 72, 65-68.

Barnes, W. S., Spingarn, N. E., Garvie-Gould, C., Vuolo, L. L., Wang, Y. Y. \& Weisburger, J. H. (1983). In The Maillard Reaction in Foods and Nutrition. ACS Symposium Series no. 215 , pp. 485-506 [G. R. Waller and M. S. Feather, editors]. Washington DC: American Chemical Society.

Correa, P., Haenszel, W. \& Tannenbaum, S. R. (1982). National Cancer Institute Monograph 62, 129-134.

Deschner, E. E. (1983). In Precancerous Lesions of the Gastrointestinal Tract, pp. 219-22 I [P. Sherlock, B. C. Morson, L. Barbara and U. Veronesi, editors]. New York: Raven Press.

Doll, R. \& Peto, R. (1981). Fournal of the National Cancer Institute 66, 1 I $9 \mathrm{I}-\mathrm{I} 308$.

Graham, S. \& Mettlin C. (1979). American Gournal of Epidemiology 109, I-1 5 .

Hiatt, H. H., Winsten, J. D. \& Watson, J. (1977). The Origins of Human Cancer. Cold Spring Harbor, New York: Cold Spring Harbor Laboratories.

Hill, M. J. (1983). In Precancerous Lesions of the Gastrointestinal Tract, pp. I-22 [P. Sherlock, B. C. Morson, L. Barbara and U. Veronesi, editors]. New York: Raven Press.

Hirayama, T. (1979). Nutrition and Cancer I, 67-78.

I.A.R.C. Microecology Group (1977). Lancet ii, 207-211.

Joossens, J. V. \& Geboers, J. (1983). In Precancerous Lesions of the Gastrointestinal Tract, pp. 97-114 [P. Sherlock, B. C. Morson, L. Barbara and U. Veronesi, editors]. New York: Raven Press.

Lipkin, M. (1983). In Precancerous Lesions of the Gastrointestinal Tract, pp. 241-254 [P. Sherlock, B. C. Morson, L. Barbara and U. Veronesi, editors]. New York: Raven Press.

Magnus, K. (editor) (1982). Trends in Cancer Incidence. New York: Hemisphere Publications.

Mirvish, S. S. (1983). Fournal of the National Cancer Institute 71, 629-647.

Modan, B., Barell, V., Lubin, F., Modan, M., Greenberg, R. A. \& Graham, S. (1975). Fournal of the National Cancer Institute 55, I 5 - 8 .

Nigro, N. D. (1981). Fat, Fiber, and Other Modifiers of Intestinal Carcinogenesis A Strategy for Prevention. Banbury Report no. 7, pp. 83-94. New York: Cold Spring Harbor Laboratories.

Pariza, M. W., Loretz, L. J., Storkson, J. M. \& Holland, N. C. (1983). Cancer Research 43, $2444 \mathrm{~s}-2446 \mathrm{~s}$.

Reddy, B. S., Cohen, L. A., McCoy, G. D., Hill, P., Weisburger, J. H. \& Wynder, E. L. (1980). Advances in Cancer Research 32, 237-345.

Reddy, B. S., Hedges, A. R., Laakso, K. \& Wynder, E. L. (1978). Cancer 42, 2832-2838.

Reddy, B. S. \& Watanabe, K. (1979). Cancer Research 39, I $521-1524$.

Sugimura, T., Sato, S. \& Takayama, S. (1983). In Environmental Aspects of Cancer: The Role of Macro and Micro Components of Foods, pp. 167-186 [E. L. Wynder, G. A. Leveille, J. H. Weisburger and G. E. Livingstone, editors]. Westport, Connecticut: Food and Nutrition Press.

Wargovich, M. J., Eng, V. M. S., Newmark, H. L. \& Bruce, W. R. (1983). Carcinogeneis 4, $1205^{-1207 .}$

Wattenberg, L. V. (1983). In Environmental Aspects of Cancer: The Role of Macro and Micro Components of Foods, pp. 157-166 [E. L. Wynder, G. A. Leveille, J. H. Weisburger and G. E. Livingstone, editors]. Westport, Connecticut: Food and Nutrition Press.

Weisburger, J. H. \& Horn, C. L. (1981). Bulletin of New York Academy of Medicine 58, 296-31 2.

Weisburger, J. H. \& Horn, C. L. (1982). In Nitrosamines and Human Cancer, Banbury Report no. 12, pp. 523-529 [P. N. Magee, editor]. New York: Cold Spring Harbor Laboratories.

Weisburger, J. H., Horn, C. L. \& Barnes, W. S. (1983). Seminars in Oncology 10, 330-341. 
Weisburger, J. H. \& Williams, G. M. (1981). Science 214, $401-407$.

Wynder, E. L. \& Cohen, L. A. (1982). Nutrition and Cancer 3, 195-199.

Wynder, E. L., Leveille, G. A., Weisburger, J. H. \& Livingstone, G. E. (I983). Environmental Aspects of Cancer: The Role of Macro and Micro Components of Foods. Westport, Connecticut: Food and Nutrition Press. 